\title{
Research-based Reflections on How the Educational, Economic and Social Circumstances Faced by Some Children and Young People Can Lead to Significant Disadvantage and Vulnerability
}

\author{
Stanley Tucker ${ }^{1}$, Dave Trotman ${ }^{1 *}$ \\ ${ }^{1}$ Newman University, Genners Lane, Bartley Green, Birmingham B32 3NT, England.
}

\section{KEYWORDS}

Children

Young People

Place

Education

Disadvantage

Vulnerability

Human Rights

\begin{abstract}
The paper provides detailed reflections on the educational, economic and social circumstances that impact on the lives of many disadvantaged and vulnerable children and young people. Drawing largely on primary research data collected in Romania, Germany and the United Kingdom, three illustrative case studies are presented for consideration focusing on: life in residential care and youth offending institutions; experiences of educational vulnerability; and human trafficking. The methodological approach adopted across the research projects explored, was shaped by the demands and expectations of the United Nations Convention on the Rights of the Child (UNCRC). All of the reported data reflects the views of children and young people who were interviewed as part of three research projects. It is argued that the difficult and challenging circumstances that many children and young people find themselves in, place them at significant disadvantage and increased vulnerability in terms of their social and educational development and life chances.
\end{abstract}

\section{Introduction}

The primary purpose in writing this paper is to provide an account of some of the significant social, educational and economic factors that can have a

\footnotetext{
*Contact address: s.a.tucker@newman.ac.uk (S. Tucker).
} 
detrimental impact on the lives of many children and young people. In citing examples of research undertaken with children and young people across Germany, Romania and the United Kingdom, it is possible to gain an understanding of how different experiences and their outcomes serve to shape the actions, expectations, self-image and life chances of particular individuals and groups. At one level the focus of attention is on place where a young person lives, school attended, community and family connections, the experience of public care, etc. At another an attempt is made to analyse how social, economic and educational factors associated with place combine to create the circumstances from which significant disadvantage and vulnerability might arise.

Indeed, it will be argued that the connection between place and disadvantaged can be extended further. For attention must also be given to the dominant discourses that frequently inform not only the representations of the young we create, but also the services that are developed and delivered in their name. As Griffin (1993) argues, some individuals and groups are systematically repressed, oppressed, denied their right to a good education, abused and blamed for the failure of others. We consistently represent young people as 'difficult', 'dangerous', 'diseased' or 'perverted'. Clearly Griffin's argument can be located within a set of dominant discourses of youth that have problematized and 'othered' their behaviour. Wetherell and Potter (1992) maintain that the 'knowledge, talk and texts' applied to the lives of young people are significant in terms of how we react and respond to them. For how we speak about children and young people and their families, research into their needs, develop services for them etc. is essentially underpinned by the views that are expressed by policy makers, those who hold sway in powerful institutions, the enforcers of legislation, professional groupings, the media, academic writers and researchers - those able to influence and shape social meanings and assist in their wider dissemination. 


\section{Methodological considerations}

One of the main concerns of the paper is to reflect on the educational, economic and social circumstances of the children and young people we engaged with. The words 'engaged with' are employed deliberately here for they mark out a particular methodological approach that was central to our research. Our intention was to build a framework for research that took account of a number of intersecting rights given to children and young people through the United Nations Convention on the Rights of the Child (UNCRC). Article 12 of the UNCRC asserts the right of the child to participate in discussions on issues that may impact on their lives. As Jones $(2004,125)$ points out, by drawing on young people's 'understandings of the phenomena that they observe, measure or are part of, new possibilities are opened up' in relation to extending knowledge and understanding, and improving the quality and relevance of educational and social policies and practices. Issues concerned with 'best interest' (article 3) in terms of participation, as well as the potential for personal 'harm' in relation to 'welfare and development' (article 36) also had to be considered. It was recognised from the outset that exploring experiences and feelings about for example educational failure or discrimination, can be difficult for some young people, and that such work requires particular sensitivity. Furthermore, in collecting research data through direct engagement, it proved possible to give those involved a level of critical voice (James and Prout 1997) underpinned by assurances of confidentiality in a climate that fostered openness, mutual respect and tolerance. Accordingly, we adopted the position, advocated by France (2004), that young people should be seen as reliable witnesses when it comes to exploring aspects of their life-worlds and as 'social actors in their own right' (O'Kane 2000, 136).

A collective case study approach (Stake 1998) is used here in order to draw together examples of common factors that proved likely to contribute towards the creation of significant disadvantage for some children and young people. Using such a method of qualitative inquiry it proved possible to produce 'thick description' (Lincoln and Grubba, 1985) from which 
emerged a number of social, educational and economic issues whose significance featured in many of the discussions held with participants. The key findings arising out of the case studies are reported below.

\section{Case studies}

\section{Living in residential care}

The first of the case studies is utilised to explore the experiences of those living in residential care and youth offending institutions. What follows is based on empirical research and published data (Bejenaru and Tucker 2014a; Bejenaru and Tucker 2014b; Tucker 2015). It is easy to locate across residential and youth offending institutions throughout Europe some of the most educationally and socially disadvantaged children and young people (see for example Berridge 2012; Hamilton-Giachritsis and Browne 2012). In Romania and the United Kingdom, as elsewhere in Europe, resources have been allocated to improve the quality of life as well as educational and social outcomes for this group of young people - though whether sufficient funding has been made available, and sufficient evaluation taken place, remains a matter for debate. Here, a range of common issues and factors that shaped the experience of care are presented for consideration. Their impact on the lives of the young people concerned is illustrated through the use of a series of direct quotes.

(1) The personal histories of almost all of the young people interviewed were underscored by chaotic and frequent transitions both between residential care homes and foster care, as well as from and within the family. Typically one young person said:

You don't stay anywhere very long drift from here to there and back... No roots, no friends and not much love...

(2) Educational success is viewed as elusive and again marked by frequent transitions between schools. Another young person said: 
Like never settling anywhere in a proper school and having a chance of doing well and teachers, one and then another.

(3) Detachment from birth and extended family with in many instances only a limited interest in establishing or re-establishing family connections displayed by young people - summed up thus:

You don't care about parents what they are or where they are... I rang a few times but gave up, nobody was interested....

(4) Brutalising youth offender regimes that foster aggression and violence. One young person said:

You learn to fight and look after yourself... If you don't, watch out for adults and the other kids.

(5) A lack of private space and an inability to keep secure personal artefacts. The view of another young person:

Hard to hold on to your life when there is nothing private that someone doesn't want to see, or steal, or make fun of...

(6) Educational underachievement that leads to an inability later in life to obtain work or gain further or higher educational qualifications. One young person who had spent a significant period of his life either incarcerated or in public care said:

There is nowhere to go now. I can't get a job or a decent training course. The courts don't even allow me to live in my own town any more.

Yes, it is reasonable to argue that some of the children and young people we interviewed had psychological, health, educational and social problems that required focused interventions. Yet in many instances it is difficult to avoid the conclusion that family, social and economic circumstances combined to generate the kind of discourses that serve to problematize the lives of those living in residential care or youth offending institutions; to create what Young $(2006,20)$ describes as an 'outgroup' who are effectively 'held at bay and excluded'. 


\section{Educational vulnerability}

In this case study specific focus is placed on young people who experience educational disadvantage and vulnerability with specific reference to those whose behaviour in school has led them to be permanently or temporarily excluded. The research referred to here was conducted in Birmingham in the United Kingdom, over a 5 year period (see Trotman et al. 2011; Tucker et al. 2015; Trotman et al. 2015). During that time it proved possible to interview over 100 young people from a variety of schools across the City of Birmingham. Although the research focused on a range of different issues definitions of risk and vulnerability, school exclusion, behaviour, curriculum relevance, etc. the primary intention of the research programme was to gain a better understanding of the day-to-day experiences of disadvantaged and vulnerable young people in schools. We undertook some initial work in 2010 with school students that focused specifically on their perceptions of risk. Following that we were contacted by a group of secondary schools in Birmingham (11-16 age group in the UK) who wanted to understand why there had been a significant increase in the number of young people being excluded from school in Year 9 (the third year of secondary school). An understanding of the key research findings can be found in the quotation presented below from our paper 'Understanding problematic pupil behaviour: perceptions of pupils and behaviour coordinators on secondary school exclusion in an English city':

'The research data brought into sharp relief the impact that poor pupil behaviour, inadequate teaching practices, insufficient resources and poorly thought-out management strategies can have on the lives of young people... Pupils did not shy away from defining what they describe as 'bad' and 'good' behaviour in the classroom. They pointed to a range of teaching and learning strategies that failed to engage them. We did not find a majority of students who 'hated' maths, or English or science; or any other subject for that matter. Indeed, for young people, quality of lessons was determined by engaging teachers, interactive pedagogy, challenge, practical application and the often used term fun $(. .$.$) .$ 
The theme of transition has emerged as a significant issue. We accumulated considerable data to support the view that the development of negative behaviour and temporary and permanent exclusion can often be punctuated by a series of 'failed' transitions. Such transitions occur between primary and secondary school in the UK, or at key points in a young person's biography. Issues of school size, the availability of appropriate support mechanisms, curriculum relevance, peer pressure and personal confidence all featured.' (Trotman et al. 2015, 14).

In talking directly to young people about their education (and their exclusion from it in many instances) data is revealed that calls into question dominant political discourse about educational reform - particularly in the UK. Indeed, it can be argued that we are now more concerned with developing targets, delivering outcomes and measuring performance than we are about pedagogical practices and what needs to be in place for all young people to achieve their potential; what Kenway (1990) terms a 'discourse of derision' based on political expediency and the creation of market relationships that set schools in opposition to each other. As Ball $(2006,121)$ argues market 'segmentation' is largely achieved through 'social and cultural bases of choice, by the constraints of choice, and by forms of selection'.

\section{Human trafficking}

The last of the three case studies focuses on the topic of human trafficking and is based on a research project developed through an international partnership (involving academic institutions in Germany, Romania and the UK) and supported through EU Daphne funding. This paper was written at a time of unprecedented movements of people across Europe and further afield, and the shocking outcomes that occur when nation states fail to support the most disadvantaged and vulnerable children, young people and women. Through the research we focused on the experiences of women and their children, young people including those who had entered another country as 'unaccompanied' and those who had fled oppressive regimes. At 
the heart of the research lay the objective of trying to understand what kind of services and support were needed to assist these highly vulnerable groups. As with other research and in accordance with a desire to adopt a human rights perspective, it was considered vital that we talked directly to children and young people about their experiences. We wanted to understand the realities of life for those who had been forced into, for example, prostitution, unpaid labour, or had travelled 'illegally' across Europe i.e. to move beyond media, political and official discursive representations. Space only permits a brief insight into what was a highly complex and multi-layered piece of work. A number of personal case studies were developed as part of the project. The power and value of listening to the stories of the young is captured in the extracts that follow (from Tucker et al. 2011).

One young person spoke of her experience of being in a forced marriage:

I was studying in a small village and was not looking to get married. I came to England on a sponsored visit (...). My visa expired and I was forced to marry my husband (...) I did not agree to this but I was far away from home and I was very scared for me and my family back home (...) I was beaten and raped by my in-laws and my uncle and made to work in my in-laws' shop from 7AM until midnight every day...

Another young person had been moved across Europe concealed in the back of a truck. He said:

I was in a truck with my brother when they opened the door and they say run away, and I run from the truck (...). They took us to the police station and left us there. I was put in a children's home, that time I couldn't speak English, just 'hello'. Problems, I just cry. My brother is somewhere else now staying in another place. I am 16 but they challenge my age, social worker and doctor don't agree. They don't know should they put me with children or adults. I miss people of my own age...

A young woman from Lithuania talked about her experiences:

A guy I met said there were jobs in Germany. I could work as a waitress. He would get me an apartment above the restaurant with 
some other girls. It would be fun. He would pay me to get set up. I could pay him back later. Could I trust him? I had heard some bad stories about girls leaving for Germany. But it wouldn't happen to me...

The research exposed significant policy and practice failures across three countries to understand and meet the needs of young people who were in danger or had been the victims of human trafficking. Those involved recounted experiences of maltreatment, neglect, abandonment, sexual exploitation and a failure to be able to secure their human rights. Difficulties in securing appropriate help and support were increased when 'matters of prosecution, surveillance, prevention and protection do not necessarily sit easily alongside each other' (Tucker et al. 2011, 144). Alongside this many examples of problematizing discourses (Griffin 1993) being used to describe the lives of trafficked children and young people could be located - these were applied to both young people themselves and their parents. Place and experience were inextricably linked in the sense that where a young person ended up frequently produced experiences of violence, abuse and sexual exploitation.

\section{Concluding thoughts}

The quotes presented in the final case study sum up the main thrust of the arguments developed within this paper. They were chosen in order to focus on the lives of some of the most disadvantaged and vulnerable children, young people and families. What binds them together is the way in which countries have failed to guarantee even basic human rights - safety, protection, education, care, etc. Countries legislate, construct policies and deliver services on the back of what might be most kindly describe as limited research; inspection processes are dominated by procedures that artificially separate outcomes from the affective domain, cultural heritage or matters of economic and class privilege; service providers build services based on problematic representations of children, young people and their families. We see the allocation of monies to the most vulnerable (such as 
those needing additional personal and educational support in schools) but it is possible to locate evidence that demonstrates that it does not always arrive at its intended target (Pop and Stănuș 2014).

Yet this discussion is about more than just reflecting on the experiences of particular groups and individual children and young people and their families. For the reality is that for those with the least power, or influence, or opportunity it is difficult to articulate what the day-to-day experience of poverty, discrimination, alienation and disadvantage is really like. For example, earlier work (see Tucker 2010) reveals how difficult it is for many disadvantaged and alienated children and young people to report abuse and neglect, and crucially be believed. Serious social disadvantage cannot be reduced to a single and simple cause. It is cumulative, deeprooted and based in experiences that are often explained through problematizing lenses (Griffin 1993). For example as Cohen (2006, xix) powerfully explains in describing the experiences of particular groups and individuals such as refugees and asylum seekers, the 'overall narratives is a single, virtually uninterrupted massage of hostility and rejection...'.

The emphasis place on the importance of understanding matters related to place and disadvantage in this paper demonstrates the need to provide a detailed level of context to the lives of individuals and groups of children and young people if their needs and aspirations are to be fully understood. The research approach adopted across the research projects cited here, focused on the value of listening to the young not least of all because they are 'reliable witnesses' (France 2004) who have important things to say about their lives. The adoption of a human rights perspective through the use of the UNCRC also provides an important backdrop against which effective advocacy opportunities can be developed. To improve the life chances of the most disadvantaged and vulnerable it is necessary to give them a more prominent voice in shaping the decisions that will a profound impact on their lives. 


\section{References:}

Ball, Stephen J. 2006. Education Policy and Social Class: The Selected Works of Stephen J. Ball. London: Routledge.

Bejenaru, Anca, and Stanley Tucker. 2014a. 'Challenging Dominant Representations of Residential Childcare in Romania: An Exploration of the Views of Children and Young People Living in the Care System.' Journal of Youth Studies 17(10): 1292-1305. doi:10.1080/13676261.2014.918250.

Bejenaru, Anca, and Stanley Tucker. 2014b. 'Voices of Youth from Romanian Residential Care Homes about Rights and Participation.' In Child and Family Welfare, edited by Patricia-Luciana Runcan, Georgeta Rață, and Mihai-Bogdan Iovu, 95-113. Cambridge: Cambridge Scholars Publishing.

Berridge, David. 2012. 'Educating Young People in Care: What Have We Learned?' Children and Youth Services Review 34(6): 1171-75. doi:10.1016/j.childyouth.2012.01.032.

Cohen, Stanley. 2006. Folk Devils and Moral Panics: The Creation of the Mods and Rockers. Abingdon: Routledge.

France, Alan. 2003. 'Young People.' In Doing Research with Children and Young People, edited by Sandy Fraser, Vicky Lewis, Sharon Ding, Mary Kellett, and Chris Robinson, 175-90. London: Sage.

Griffin, Christine. 1993. Representations of Youth: The Study of Youth and Adolescence in Britain and America. Feminist Perspectives. Cambridge: Polity Press.

Hamilton-Giachritsis, Catherine, and Kevin Browne. 2012. 'Forgotten Children? An Update on Young Children in Institutions across Europe.' Early Human Development 88(12): 911-14. doi:10.1016/j.earlhumdev.2012.09.018.

Jones, Adele. 2004. 'Involving Children and Young People as Researchers.' In Doing Research with Children and Young People, edited by Sandy Fraser, Vicky Lewis, Sharon Ding, Mary Kellett, and Chris Robinson, 113-30. London: Sage.

Kenway, Jane. 2012. 'Education and the Right's Discursive Politics: Private versus State Schooling.' In Foucault and Education: Disciplines and Knowledge, edited by Stephen J. Ball, 167-206. London: Routledge.

O'Kane, Claire. 2000. 'Facilitating Children's Views about Decisions Which Affect Them.' In Research with Children: Perspectives and Practices, edited by Pia Monrad Christensen and Allison James, 136-59. London: Falmer Press. 
Pop, Daniel, and Cristina Stănuș. 2015. The Governance of Educational Welfare Markets. New York: Peter Lang.

Stake, Robert E. 1980. 'Case Studies.' In Strategies of Qualitative Inquiry, edited by Norman K. Denzin and Yvonna S. Lincoln, 437-54. London: SAGE.

Trotman, Dave, Madeline Martyn, and Stanley Tucker. 2012. 'Young People and Risk.' Pastoral Care in Education 30(4): 317-29. doi:10.1080/02643944.2012.702779.

Trotman, Dave, Stanley Tucker, and Madeline Martyn. 2015. ‘Understanding Problematic Pupil Behaviour: Perceptions of Pupils and Behaviour Coordinators on Secondary School Exclusion in an English City.' Educational Research 57(3): 237-53. doi:10.1080/00131881.2015. 1056643.

Tucker, Stanley, Madeline Martyn, Anca Bejenaru, Graham Brotherton, Silke Gahleitner, Connie Gunderson and Horațiu Rusu. 2011. Violence, Exploitation and Human Trafficking: Service User Perspectives. European Commission's Daphne 111 Programme 2007-2013. Birmingham: Newman University Children, Young People and Families Research Centre.

Tucker, Stanley. 2011. 'Listening and Believing: An Examination of Young People's Perceptions of Why They Are Not Believed by Professionals When They Report Abuse and Neglect: Listening and Believing.' Children \& Society 25(6): 458-69. doi:10.1111/j.1099-0860.2010.00291.x.

Tucker, Stanley. 2011. 'Reflections from the Margins: White Working Class Boys, Educational Underachievement and Uncertain Futures.' Social Change Review 8(2): 101-119.

Wetherell, Margaret, and Jonathan Potter. 1992. Mapping the Language of Racism: Discourse and the Legitimation of Exploitation. New York: Columbia University Press.

Young, Jock. 2006. The Exclusive Society. Thousand Oaks: Sage. 